Kristian Wedberg

Doktorgradskandidat ved Institutt for informasjons- og medievitenskap

Det samfunnsvitenskapelige fakultet

Universitetet $i$ Bergen

\title{
Den store forfatters tale: Om Solstads sakprosa
}

\begin{abstract}
In 1997, the Norwegian writer Dag Solstad published a newspaper article with the title Om meddelelsens problem (The problem of communication), which gained much public attention, and soon became a standard reference in debates about the role of the intellectual writer in Norway. I analyze the linguistic-rhetorical characteristics of the text. The main elements are two anecdotes from Solstad's personal experience, which exemplify and generalize his claim of a decadent public sphere. Using long-winded sentences, repetitive phrases and meticulous syntax, Solstad dissimulates a textual persona that demonstrates an alternative mode of publicness. His article is thus an example of taking "literary action" and constitutes a mimetic argument for the importance of literary communication.
\end{abstract}

27. juni 1997 hadde Dag Solstad en kronikk i Aftenposten med tittelen Om meddelelsens problem (Solstad, 1997). ${ }^{1}$ Kronikken var et svar på et tidligere innlegg av Vidar Kvalshaug, Forarget over etablerte forfattere, der Solstad og en rekke andre norske forfattere ble kritisert for sin tilårskomne sidrumpethet, navlebeskuende litteraturbetraktninger, tendens til isolasjon og manglende evne til å se "at verden utenfor rører på seg” (Kvalshaug, 1997). Solstads svar var at det er umulig å være intellektuell i Norge fordi vi ikke har noen opplyst allmennhet. Den norske offentlighet er befolket av overflatiske kulturkonsumenter for hvem et intellektuelt budskap alltid vil falle på steingrunn. Da er det kanskje bedre å ikke si noe i det hele tatt, men slik talende taushet er uforenlig med den intellektuelles rolle. Den intellektuelle forfatter står ifølge Solstad overfor et dilemma: Hvis han ytrer seg offentlig, trivialiseres budskapet; hvis han forholder seg taus, forsømmer han sin plikt til politisk deltagelse.

\footnotetext{
${ }^{1}$ Essayet som ble trykket i Aftenposten var en forkortet versjon av et foredrag som ble holdt for norsklærere i 1996. Begge versjonene er utgitt i samlingen 3 essays (Solstad, 1998), hvor Solstad også kommenterer forholdet mellom de to tekstene.
} 
Imidlertid falt Solstads meddelelse om meddelelsens umulighet i god jord siden den avfødte en umiddelbar og omfattende respons i den norske offentlighet. ${ }^{2}$ Hva var grunnen til at dette stykket sakprosa forårsaket et slikt intenst ordskifte?

Dag Solstad har en enestående posisjon i norsk offentlighet. Det foreligger fem avhandlinger om ham, tallrike artikler, avisintervjuer og presseoppslag, og nylig kom det ut et 500 siders portrettintervju i bokform. Både blant kritikere og i akademia er det en utbredt oppfatning at Solstad er vår tids største norske romanforfatter. Hensikten med denne undersøkelsen er imidlertid ikke å belyse Solstads skjønnlitteratur, men å se på "Om meddelelsens problem” som en sak for seg. Jeg ønsker å undersøke hva jeg finner når jeg tar Solstad på ordet og betrakter hans tekst om meddelelse som meddelelse. I tillegg til å høre hva han sier, vil jeg se hva han gjør; jeg vil betrakte Solstads meddelelse som en retorisk handling.

Én innfallsvinkel til den retoriske virkemåten er å studere den responsen teksten faktisk fikk. Jeg vil ikke her foreta en systematisk gjennomgang av resepsjonen, ${ }^{3}$ bare gi et inntrykk av den. I ukene etter Solstads innlegg sommeren 1997, ga forfattere som Jan Kjærstad, Kjetil Bjørnstad, Tor Obrestad, Arne Berggren, John Erik Riley, Vigdis Hjort, samt en rekke akademikere, journalister og kritikere, bidrag til det som skulle bli sommerens intellektuelle føljetong. Debatten spredte seg raskt fra Aftenposten til flere andre aviser, etter hvert også til medier i andre nordiske land. Responsen var overveiende negativ. Her er noen av lesernes karakteristikker: "umoralsk nostalgi" (Lending, 1997), "pinsamt reaktionära utgjutelser" (Gabriella Håkansson i Økland, 1998), "kvinnediskriminerende” (Märta Tikkanen i Økland, 1998), og "kjedelig" (Riley, 1997). Men samtidig var det påfallende enighet om at dette var usedvanlig godt skrevet. Mer eller mindre motvillig ga man uttrykk for at teksten hadde sterk appell; Jan Kjærstad "griper seg selv" i å "applaudere, humrende" (Kjærstad, 1997), John Erik Riley synes “det er en vakker tekst Solstad har skrevet [...] om aldri så "irriterende" (Riley, 1997), Marit Tusvik fant Solstads "mumling" "vidunderlig" (Tusvik, 1997), Ingunn Økland fremhevet den "elegante formen" til tross for det "påstått reaksjonære innholdet" og mente essayet var ett av "tiårets tre beste norske essays" (Økland, 1998). Det var utvilsomt noe paradoksalt ved denne mottakelsen, som om Solstads dilemma hadde sitt motstykke i publikums ambivalens. Men kan man slå seg til ro i en leserposisjon der man nyter formen og forakter innholdet? ${ }^{4}$ Det at Solstads meddelelse faktisk ansporet til slike splittede lesninger er et poeng vi skal ta med oss gjennom den følgende analysen. Hva er betydningen av, eller forklaringen på, det tilsynelatende paradoksale forholdet mellom innhold og form i Solstads meddelelse?

\footnotetext{
${ }^{2}$ Debatten er gjennomgått og analysert i hovedoppgaven Littercer offentlighet og opplysningens dilemma (Wedberg, 2003).

${ }^{3}$ For en slik gjennomgang, se Wedberg (2003). Se også Østenstad (2009: 305-306).

${ }^{4}$ I debatten formulerte Jan Kjærstad dette poenget slik: "Solstad latterliggjør sine beundrere, mens de igjen og igjen svarer med et: Pisk oss mer! Det er som om Solstad i bok etter bok ber om motstand, mens man svarer med å hylde ham. (...) Jeg har aldri klart å løse denne gåten: Solstads forakt for norsk kulturliv, forakt for nordmenns lave intellektuelle nivå - og så trofastheten i Solstads leserskare og i den offentlige respons” (Kjærstad, 1997).
} 


\section{Forbilledlighet}

Solstads kronikk begynner slik:

Rett før jeg skulle opp til examen artium våren 1960, holdt min norsklærer en innstendig formaningstale til elevene i $5 \mathrm{RG}$ ved Sandefjord høyere skole om hva vi for alt i verden ikke måtte finne på når vi satt med oppgavene i norsk stil foran oss. Fra denne lange tiraden husker jeg bare én ting, og det var en skrekkhistorie. Noen år i forveien hadde en av hans flinkeste elever strøket i norsk stil. Hun hadde valgt en litterær oppgave hvor hun skulle drøfte et alment moralsk dilemma med utgangspunkt $i$ et selvvalgt litterært verk. Hun hadde drøftet dette etter alle de regler som gjaldt for å drøfte et slikt moralsk dilemma, men like fullt hadde hun, som aldri i sin gymnastid hadde fått dårligere enn meget på sine stiler, strøket. Årsaken var at det verk hun hadde valgt til å eksemplifisere drøftingen, var et verk av Evi Bøgenæs, en da kjent ungdomsbokforfatter. På grunn av dette sto hennes ellers fortrinnlige besvarelse til blank stryk. For min lærer var det også uomtvistelig; han kom ikke med denne skrekkhistorien for å advare oss mot uberegnelige sensorer, men for å understreke at intet hjalp oss hvis vi ikke greide å fremstille oss som modne i vår besvarelse. Vi som var hans elever, hadde ingen problemer med å skjønne dette. Det forekom oss selvsagt at det kvalifiserte til stryk til examen artium hvis man drøftet almene moralske dilemmaer med utgangspunkt $\mathrm{i}$ en ungpikeroman av Evi Bøgenæs.

I dag er det jo omvendt. Ja, så omvendt at $[\ldots]^{5}$

Med en forenkling kan man si at strukturen er slik: Først bruker en elev en bok som eksempel på et moralsk dilemma; deretter bruker læreren elevens bokanalyse som et eksempel på en mislykket eksamensbesvarelse, og til sist bruker Solstad lærerens formaningstale som et eksempel på en kontroversiell (men for Solstad forbilledlig) holdning. Retorisk sett det dreier seg altså om eksemplifisering i forskjellige faser og nivåer, det er på sett og vis forbilledlighet som sådan (exemplum - para-deigma - for-bilde) som her introduseres. For å få et grep om denne forbilledlighetens betydning og funksjon må vi se nærmere på dens form og innhold.

Typisk for et debattinnlegg $i$ en avis er at man umiddelbart uttrykker sitt anliggende og i vårt tilfelle kunne man forvente en referanse til Kvalshaugs innlegg. Men Solstad gjør noe annet: "Rett før jeg skulle opp til examen artium [...]" Vi er brått in medias res, inni en personlig erindring. Her er ingen referanser til det temaet Kvalshaug reiser, og den saklige relevansen av erindringen er innledningsvis langt fra innlysende. Fortellingens språk er, i denne sammenheng, langtrukket og omstendelig, med lange setninger og detaljrike innskytelser som "[...] elevene i 5RG ved Sandefjord høyere skole [...]” som stadig gjentas.

$\AA ̊$ begynne med en fortelling med uklar relevans er et brudd med den tekstøkonomi som ellers preger avisinnlegget som genre. I et konvensjonelt journalistisk perspektiv er ikke dette effektiv formidling av et synspunkt. Formmessig er det også ukonvensjonelt:

\footnotetext{
${ }^{5}$ Tekstsitater i denne artikkelen er fra "Om meddelelsens problem" hvis ikke annet fremgår.
} 
Innledningen er strengt tatt ingen innledning, det er bare en begynnelse. Eller man kan si at nettopp dét er innledningen: Å skape en umiddelbar retorisk effekt ved at noe er utelatt. Dette kan virke til enten å irritere leseren eller å vekke hans interesse. Den utålmodige leser vil savne opplysninger om hva det hele skal handle om og vil kunne falle av. Kontrakten med den gjenværende leser bygger på et insentiv: Den tålmodige vil få avkastning på sin investerte oppmerksomhet. Slik får forfatteren en aura av eksklusivitet: Han er den som kan tillate seg å bryte med den konvensjonelle form og utsette belønningen, og på den måten få en leser som han fortjener.

Handlingen i eksempelet foregår i et klasserom. Undervisning i et klasserom ligner en offentlig situasjon: Læreren trer frem og formidler sin kunnskap for et publikum (elevene). Også tematisk fungerer klasserommet som en analogi; en analogi for det offentlige rom. Lærerrollen og den intellektuelles rolle bindes slik sett sammen av et bilde av fortellende opplaering, og i forlengelsen av dette: folkeopplysning. Dette er for øvrig et motiv som står sentralt i Solstads forfatterskap generelt. Læreren figurerer hyppig i Solstads romaner, blant andre Professor Andersens natt, Gymnasloerer Pedersens beretning om den politiske vekkelse som har hjemsøkt vårt land og Genanse og verdighet.

Klasserommet etablerer et bilde av et sosialt rom, og gir leseren et øyeblikks erfaring av gruppeidentitet, om enn bare i et kort glimt, slik en filmregissør benytter seg av svart/hvittsekvenser for å illudere en historisk hendelse. Dette historiske rommet står i kontrast til nåtidens offentlige rom, som er blitt et sted for mer eller mindre tilfeldige sammenstøt mellom konsumenter som er ute og handler på idéenes markedsplass. Solstad demonstrerer ved hjelp av eksempelet, at samfunn er noe som har vort. Jeg vil ikke her gå inn på en vurdering av Solstads beskrivelser. Poenget i denne sammenheng er å vise hvordan Solstad gjennom sin fortelling skaper et konkret bilde av det tema han diskuterer. Leseren blir så å si brakt inn i klasserommet via fortellingen, hvor han befinner seg som en imaginær observatør. Gjennom den (etter forholdene) konkrete beskrivelsen settes vi i en kvasi-erfarende tilstand. Bruken av anekdoten skjerper leserens oppmerksomhet og persepsjon, og forbereder oss på den forestående diskusjon.

Et beslektet poeng er at Solstad trekker veksler på leserens potensial for gjenkjennelse. Situasjonen hvor elevene lytter til lærerens formaninger vil vekke gjenkjennelse og assosiasjoner hos de fleste. Anekdoten bringer oss imidlertid ikke bare i kontakt med vår fortid, den foregir også å bringe oss nærmere vår nåtid gjennom en appell til den hverdagslige erfaring. Anekdotens retorikk inneholder en stilltiende appell: 'La oss for et øyeblikk se litt nærmere på hva vi egentlig snakker om.' Dette betyr ikke at leseren nødvendigvis må få sympati med den situasjonsbeskrivelsen som gis, og langt mindre med tolkningen av den. Han vil imidlertid være tilbøyelig til å akseptere forfatterens ambisjoner om å gi en noenlunde sannferdig fremstilling av en hendelse, slik den sto for ham, slik han oppfattet den. Denne implisitte påstanden om sannferdighet ligger i selve eksempelets realistiske form, og er en av dens sentrale retoriske virkninger. Selv om resultatet av virkelighetsutforskingen vil tolkes forskjellig fra leser til leser, vil man likevel ha hatt en realistisk erfaring gjennom 
leseprosessen, nemlig den at forfatteren har hatt en intensjon om å beskrive det hele som det faktisk fremsto for ham.

Endelig kan vi peke på at selve den hendelsen anekdoten beskriver, lærerens formaningstale, fungerer som en formal analogi til Solstads egen tekst, ettersom den også er en slags formaningstale. Ved å referere lærerens tale, og den domsavsigelse den munnet ut $\mathrm{i}$ (dommen over eleven som strøk), har Solstad engasjert leseren til å felle sin egen dom. Han antar at de fleste lesere vil finne det urimelig å stryke en elev på et slikt grunnlag som det refereres til. Det er nettopp denne forventede indignasjonen Solstad spiller på, når han senere tilkjennegir at han deler tidligere tiders konservative vurderinger, og ikke nåtidens liberale holdning. Solstad lokker eller provoserer leseren til å innta bestemte standpunkter, som han siden gjendriver. Slik driver Solstad gjøn med en leser han selv finner opp. Det er dette Kjærstad er inne på når han sier at Solstad latterliggjør sitt publikum.

Gjennom formaningstaleeksempelet får Solstad dessuten leseren til å danne seg et bilde av en situasjon som er lik den situasjonen leseren selv befinner seg i når han leser Solstads tekst, altså det å overvære en formaningstale. ${ }^{6}$ Solstad har dermed via en analogi foregrepet den form for retorikk som teksten som helhet iverksetter. Analogien fungerer ved å skape en hermeneutisk ramme, en horisont for forståelsen av den videre argumentasjon. Han har aktivert leserens sans for rettferdighet ('var det virkelig nødvendig å gi eleven stryk?'), og appellert til hans dømmekraft ('hva ville du gjort?') og empati ('stakkars elev!'). Dette kan forfatteren siden utnytte til sin retoriske fordel: Først etableres lærerens tale som en tekst $\mathrm{i}$ teksten; parallelt med dette dannes det en fortolkningsramme hos leseren; dernest kommer Solstads egen fortolkning som fremstår som overlegen, fordi Solstad tross alt har regissert det hele fra begynnelsen.

Ironisk nok ligger det i denne orkestreringen et element av umyndiggjøring, som om Solstad ikke tar leseren helt på alvor. Samtidig bør man være oppmerksom på at det også ligger en skjult appell her: Solstad appellerer til dem som gjennomskuer hans lett foraktfulle retorikk. Hans forakt for den jevne leseren er samtidig en appell til den intelligente leser. Slik skapes en eksklusiv leserkrets på bakgrunn av et skille mellom den gode og den dårlige leser. ${ }^{7}$ Dette er for øvrig et tilbakevendende tema i Solstads forfatterskap: hans etterlysning av den

\footnotetext{
${ }^{6}$ Det er verdt å merke seg at teksten med sin eksempel-struktur ligner en veletablert retorisk genre, nemlig prekenen. Prekenen tar også utgangspunkt i en historie, for eksempel en bibelsk lignelse eller en hverdagslig hendelse, som gis en forsøksvis oppbyggelig tolkning. Presten presenterer et kasus for menigheten, som han tolker for oss, på vegne av oss, til vår tjeneste. Han innskriver våre erfaringer i en bestemt narrativ ramme. Med en analogi kan man si at hvis offentligheten er kirken, så er den litterære intervensjon en sekulær preken. Med utgangspunkt i egne erfaringer angir forfatteren en narrativ ramme som på vegne av oss, menigheten, publikum, offentligheten, gir erfaringsfragmenter en sammenheng, en helhet. ${ }^{7}$ Solstad har for vane å uttale seg om sine lesere. Til Aftenposten sa han dette i et intervju med tittelen "Vil ikke ha Fr.p.lesere": "I motsetning til mange andre norske forfattere har jeg gode lesere" (Skre, 2002). Her er en indikasjon på hvem han sikter til med "andre forfattere": “Jeg har truffet noen av Kjærstads lesere. Jeg er glad de ikke er mine [...]” (Sørensen, 1997).
} 
gode leser og generelle misnøye med den litterære kritikken. ${ }^{8}$ Det er også et vesentlig element $\mathrm{i}$ hans uttrykte misnøye med den norske offentlighetens intellektuelle standard.

I kraft av eksempelets realisme aktiverer Solstad leserens observasjons -og persepsjonsevne og styrker sin ethos som forteller. Dette har han gjort bl.a. via innbildning og delvis skjulte analogier. Med dette har Solstad bearbeidet premissene i den aktuelle situasjonen og forsøkt å endre resepsjonens forutsetninger. De elementer som i kombinasjon definerer talesituasjonen, altså den polemiske utfordring, avisinnleggets genrekrav, de journalistiske krav til tekstøkonomi, informasjonstetthet osv., er gjort synlige og relativert. Dermed er publikum gjort mer mottagelig når den egentlige overbevisning skal begynne. Det er således et nært forhold mellom tekstens innledning og den situasjonen han går ut fra. Når det gjelder Solstads utgangspunkt som taler, er hans tillit til det brede publikums dømmekraft og vurderingsevne liten (hvis vi skal tro Solstads egne uttalelser). Samtidig må en tale nødvendigvis appellere til publikums vurderinger. Talen får dermed preg av en splittethet, som gjenspeiles i at retorikken fungerer på to nivåer. På ett nivå skyver han sitt publikum fra seg, på et underliggende strukturelt nivå appellerer han til publikums tillit. En hypotese kan være at disse to nivåene forenes i hans ærlighet: Hans avvisning av publikum kan samtidig oppfattes som et uttrykk for oppriktighet. Hvem er denne mannen som tillater seg å bryte alminnelige prinsipper for offentlig kommunikasjon?

Denne dobbeltkommunikasjonen, som består $\mathrm{i}$ å skape tillit iblant et publikum han selv ikke har tillit til, er særlig påtrengende akkurat i det øyeblikk Solstad trer inn på podiet. Kontrakten med publikum må settes opp raskt. Solstad forsøker å etablere tillit i det skjulte, gjennom bestemte formmessige grep. Dette har avgjørende betydning for Solstads retorikk, idet det medfører en form for spill med publikum. Dette resulterer i, som vi skal komme nærmere inn på siden, en form for forstillelse og ironi.

Det er ikke dermed sagt at det har lyktes Solstad å etablere troverdighet, det kan tenkes lesere som stiller andre krav til det, for eksempel en tydelig velvilje overfor tilhørerne. Solstad har derimot en viss distanse til publikum, i hvert fall til deler av publikum. Dette kan betraktes som en slags antiretorisk strategi, der det å unngå å etterkomme publikums antatte forventninger er et mål i seg selv. Men det kan også sees som et ledd i forsøket på å restrukturere situasjonens forutsetninger: gjennom et slags eksklusivitetsprinsipp henvender han seg til den utvalgte leser, smigrer ham som en av de 'happy few', og gjør det lettere å få gjennomslag for sin retorikk. Dette betyr i praksis at han snevrer inn leserkretsen til dem som i utgangspunktet er mottagelig for hans synspunkter. Hvis Solstad skal drive opplysning, skal det skje blant likesinnede og på Solstads egne premisser, dvs. i fortrolighet mellom Solstad og den utvalgte leser. Slik sett kan man si at Solstads form for kommunikasjon er esoterisk.

\footnotetext{
${ }^{8}$ Se for eksempel essayet Om romanen (Solstad, 1998) som er en kritikk av anmeldelsene av hans egne romaner.
} 


\section{Offentlighet}

Solstads kronikk inneholder to anekdoter. Den andre anekdoten handler om en doktordisputas og lyder slik:

Før jeg nå går videre $\mathrm{i}$ å snakke om meddelelsens problem, altså om de intellektuelles funksjon, vil jeg fortelle en annen selvopplevd historie. Den foregår i 1985, altså 25 år etter den første historien, og ti år før den tid vi hensleper oss $i$ akkurat nå. Det var i Gamle Festsal på Oslo Universitet. En venn av meg skulle disputere for den filosofiske doktorgrad. Han var betraktet som en stor filosofisk begavelse, og nå forelå endelig hans doktoravhandling som drøftet spørsmål i forbindelse med Immanuel Kants filosofi. Intet mindre. Man skulle tro Gamle Festsal var overfylt av filosofer, lærere og studenter som åndeløst fulgte denne begivenhet. Men nei. Filosofene glimret stort sett med sitt fravær. I salen satt det rett nok en god del folk, det var doktorandens venner, og av dem var en del også filosofer, rett skal være rett. Men det var likevel fă tilstede av dem dette burde være, og egentlig var, en begivenhet for. Så kom prosesjonen. Opponentene og doktoranden marsjerte inn, etter eldgammel skikk, først én opponent, så doktoranden, og til slutt annenopponenten. Vi, doktorandens venner, falt sammen, tvekroket av undertrykt latter.

Det var så komisk å se ham marsjere inn på denne måten, i en avlagt høytidelighet, sprutrød i hodet, stiv som en stokk, mellom sine to opponenter. Egentlig var det førsteopponenten som skapte denne komikken, for han gikk først og bestemte tempoet, og tempoet var høyt. Latterlig høyt. Prosesjonen kavet med andre ord, for å berge seg inn på land så fort som mulig. Det minnet om et sammenbrudd, og det var det det var. Stilen hadde forlatt den akademiske institusjon, og det var da jeg oppdaget at den i og for seg godt besøkte Gamle Festsal var befolket av utenforstående, doktorandens venner. Dette var en begivenhet bare for dem som det ikke angikk, for dem det angikk var det ingen begivenhet, i hvertfall ikke så stor at de hadde funnet det nødvendig å være til stede, og bli sett. Det var betenkelig. Det var første gang jeg forsto at en epoke var over, og at jeg selv befant meg i stor fare, som intellektuell.

Solstads gjenfortelling om doktordisputasen er en forfallshistorie. Det er en eksemplifisering av det historiske øyeblikk da det offentlige rom ble privat. Et nøkkelord er sammenbrudd: "Det minnet om et sammenbrudd, og det var det det var." Jeg vil først se nærmere på hva som ifølge Solstad karakteriserer dette sammenbruddets øyeblikk, og deretter vise hvordan avsløringen av det komiske henger sammen med Solstads overordnede retoriske prosjekt.

Universitetet er samfunnets høyeste akademiske institusjon, og en doktorgrad er den høyeste grad som kan oppnås innen det akademiske system. En doktordisputas er dermed i utgangspunktet en høytidelig, offentlig begivenhet. Høytideligheten viser seg blant annet gjennom det rituelle og det seremonielle. Seremonien innledes med en prosesjon der doktoranden trer inn på podiet mellom de to opponentene. Men på dette tidspunkt viser bruddet seg: de rituelle, seremonielle og høytidelige formkrav som ligger innbakt i 
situasjonen som forventninger, kan ikke innfris av de involverte personer. Dette skinner igjennom når de øker tempoet på prosesjonen for å forsøke å unnslippe det seremonielle så fort som mulig. Dersom de isteden hadde gjort gode miner til slett spill, vært litt mer tålmodige og gått inn på scenen i et adekvat tempo, kunne de kanskje ha holdt sin usikkerhet skjult for publikum. Isteden er det nettopp den unnvikende handling, tempoøkningen, som avslører dem for publikum, fordi denne er objektivt synlig. Det (innbilt) private blir offentlig og dermed stilles de opptredendes usikkerhet til skue.

Det er nettopp i kollisjonen mellom det private og det offentlige at det komiske oppstår. Deltagernes holdninger (eller mangel på sådanne) bidrar til å undergrave begivenhetens høytidelighet. I deltakernes bevissthet oppleves dette som noe privat, noe som må holdes skjult for publikum. Doktoranden oppfatter intuitivt at han undergraver sin egen autoritet hvis han viser usikkerhet, det er jo tross alt han som står i begivenhetens sentrum, og det er unektelig noe paradoksalt ved det å vise frem sin egen manglende tro på autoriteten $\mathrm{i}$ den institusjonelle handling som skal hedre deg. Problemet er at disse tankene blir forsøkt holdt privat gjennom en handling som er offentlig i og med den situasjonen han befinner seg i; man kan ikke velge å opptre privat i en slik situasjon. Idet man står foran et publikum er alle handlinger offentlige enten man vil det eller ikke; de blir det ut fra en sosial lovmessighet. Det er dette misforholdet mellom personenes illusjon om subjektiv valgfrihet og den sosiale objektive nødvendighet som tilskuerne observerer og gjennomskuer, som oppfattes som komisk. Deltakerne er skuespillere som ikke ønsker å spille den rollen de er tildelt. De ender dermed opp med å spille en tredje, alternativ rolle, nemlig rollen til en som prøver å komme seg ut av stykket så fort som mulig. I stedet for teatral seriøsitet overværer vi en virkelighetens farse.

Komikken er ufrivillig; det ligger ingen forventning om at det skal oppstå noe komisk $i$ en situasjon som dette. Komikken er en sosial bivirkning, utenfor de deltagende personers eller publikums kontroll. Den lever sitt eget liv, bryter inn i situasjonen utenfra, uten forvarsel; den oppstår så å si på et metasituasjonelt nivå. Tilsvarende gjelder for den som forteller om dette: Skal komikken formidles, må den vises frem i og med 'historien rundt', nærmest på et metanarrativt nivå. Den kan ikke gripes eller fortelles direkte. Det morsomme i en vits utløses når poenget kommer, men hvis du ikke ler, hjelper det ikke å tydeliggjøre poenget etterpå, det er ikke 'poenget i seg selv' som utløser humoren. Forklaringen av poenget reduserer historiens fylde til en abstraksjon. Det komiske i hendelsen viser seg i det konkrete, i den unike konstellasjonen av hendelsens utvendige, karakteristiske trekk, i dens sosiale, materielle manifestasjon. Og for å få denne konstellasjonen til å vise seg, eller tre frem, må hendelsen fortelles på nøyaktig denne måten.

Det er her historiefortelleren, forfatteren, kommer inn. Solstad iverksetter sin talehandling gjennom å vise frem en begivenhet slik at vi forstår at dette måtte fortelles akkurat slik for å få frem hendelsens vesentlige trekk (dens komikk). Gjenfortellingen demonstrerer et element av eksklusivitet. Solstad viser at han fanger noe som ikke ligger oppe i dagen, et aspekt eller en tolkning av situasjonen som krever et observant forfatterblikk. På basis av hans observasjoner kan hendelsen gis en meningsfylt tolkning, en fragmentert 
begivenhet kan settes sammen til et meningsfylt hele. Ved å fortelle om begivenheten viser han ikke bare akkurat denne spesielle historiske hendelsen 'slik den virkelig var', men han viser også på et allment plan hvilke sider ved våre liv som vi risikerer å la gå fra oss, uoppdaget og ubeskrevet, og dermed glemt. Solstad blir således talsmann for den form for kollektiv hukommelse som historiefortelling representerer.

Solstad omtaler gjentatte ganger disputasen som en begivenhet. Men så viser det seg at denne disputasen ikke er en begivenhet "for dem det burde være en begivenhet for", dvs. for akademikere og intellektuelle, men kun for doktorandens familie og venner. Men ved å fortelle om disputasen, viser Solstad hvordan disputasen kunne ha voert en begivenhet. Publiseringen av fortellingen omdanner hendelsen til en historie, og gjør den til en begivenhet for dem som leser om den.

\section{Virkelighetstap}

Når det offentlige forfaller, snevres vår verden inn. Våre blikk vendes innover, og livsverden kollapser $\mathrm{i}$ en latterlig, innbilt individuell og privat verden, lik den opponentene og doktoranden trodde de befant seg $\mathrm{i}$ da de forsøkte å riste av seg situasjonens pinlighet gjennom å øke tempoet i den doktorale inntogsmarsj. Med det samme overbærende smil som Solstad bivånet den komiske parade, betrakter han dagens offentlighet som en samling selvtilstrekkelige individer som ikke er seg bevisst sin egen offentlighet. Det er også den samme overbærenhet som læreren utstrålte gjennom sin skrekkhistorie om den 18 år gamle gymnasiasten som ikke så sin eksamensbesvarelse som en offentlig handling.

Tap av offentlighet innebærer ikke bare at vilkårene for informert og intellektuell samtale forstummer; det er noe mer enn Habermas' pragmatiske prinsipp om herredømmefri dialog som her står på spill. Tap av offentlighet er tap av virkelighet. For Hannah Arendt betyr 'offentlig' blant annet at "alt det som trer frem for allmennheten er synlig og hørbart for alle og enhver [...] At noe trer fram og oppfattes slik både av andre og oss selv, betyr i menneskenes verden at det får virkelighet” (Arendt, 1996: 63). Tanker og følelser i vårt indre liv lever en "usikker, skyggeaktig tilværelse, forutsatt at de ikke forvandles, liksom avprivatiseres og avindividualiseres og i den grad omdannes at de antar en form som egner seg for offentlig fremtreden." Slik formgivning kan skje i kunsten, eller når vi "forteller en enkel historie", eller simpelthen når vi "snakker om ting" (Arendt, 1996: 63).

I en tiltagende intimisert offentlighet svekkes individenes tillit til den ytre virkelighet og den objektive verden som omgir oss: "[...] selv om det private indre livets fullt utviklede intimitet, som skyldes den nyere tid og det offentliges forfall, har beriket og utvidet skalaen av subjektive følelser til det ytterste, så kunne denne intensiveringen bare komme i stand på bekostning av tilliten til verdens virkelighet og til menneskene som fremtrer der" (Arendt, 1996: 63).

I The Fall of Public Man beskriver Richard Sennett det offentlige rom som et område hvor man opptrer under dekke av masker (personae). Disse skapes nettopp for å markere distanse til det private selvet og derved sikre en sivilisert sosial opptreden, hvor man ikke 
belemrer andre med krav om nærhet og intimitet. "In a world without religious rituals or transcendental beliefs, masks are not ready-made. The masks must be created by those who will wear them, through trial and error, through a desire to live with others rather than a compulsion to get close to them" (Sennett, 1977: 264). A lage seg en maske er en adekvat respons på en offentlig situasjons formkrav. Det er kun ved en form for forstillelse at en person kan tre inn på den offentlige arena uten å være bundet og hemmet av den private nærhetens og intimitetens ideologi. Slik forstillelse sikrer det sivile liv, det vil si livet i et moderne, urbant samfunn.

Det å skape en maske krever et element av kreativitet og en viss estetisk sans. Med en metafor kan man si at det krever evnen til å spille en rolle, og evne til å regissere seg selv på den offentlige scene. Dersom den offentlige opptreden for eksempel består $\mathrm{i}$ å holde tale, skapes tilsvarende en bestemt retorisk maske. Som forfatter skaper man en tekstlig maske, en tekstlig persona.

Solstads fortelling om doktoranden som ikke kunne fremvise den nødvendige forfengelighet, er en fortelling om det symptomatiske fravær av evnen eller viljen til å lage en maske. I en viss forstand var dette en logisk følge av det faktum at salen ikke var befolket av personer med faglige motiver for å være tilstede, snarere av familie og venner, hvis interesse for begivenheten var av familiær karakter. I familiære situasjoner er rollespillet underforstått og upåfallende. Forlegenheten over å måtte opptre i henhold til rituelle formkrav var en naturlig respons på det faktum at begivenheten ikke var offentlig, men et privat festarrangement, i hvilken ethvert åpenlyst rollespill ville bli avslørt som falskhet og hykleri.

Tidlig i sitt forfatterskap ga Solstad selv uttrykk for at forstillelse var et tema i tekstene hans. I essayet Nødvendigheten av å leve inautentisk tar han utgangspunkt i en tolkning av Gombrowicz' forfatterskap, og knytter denne tolkningen til en analyse av begrepene Form og 'inautentisitet'. Dette munner ut i et frigjøringsprosjekt:

Inautentisitet fordi dette begrepet gir livet en retning å bevege seg mot, som fører langt, langt bort fra alle idealistiske, romantiske og borgerlig humanistiske fantomer. En retning som angir et mer realistisk syn på mine muligheter i en verden hvor jeg daglig opplever på kroppen at jeg må gjøre opprør for å hindre å bli bundet i noe jeg ikke har lyst til å bli bundet til. Bevissthet, spill, og konstruksjoner fordi disse begrepene gir distanse, innsikt, og handlefrihet i en verden som for tiden ikke er etter mitt hode (Solstad, 2000).

Masken, i den Solstadske varianten, er den språklig-retoriske konstruksjon som gjør oss i stand til å forlate den private, borgerlige verden og tre inn i den offentlige verden, hvor mening skrives. Masken er en interface i bokstavelig forstand, det er ansiktet til det private subjektet slik det viser seg for et publikum. Masken og Formen oppstår som en respons på kravene om en distinkt offentlig sfære, en sfære hvor verden med-deles gjennom at man omskaper seg selv til en form som er åpen og tilgjengelig for andre. Forfatterens rolle er å raffinere Formen og maskene, slik at den delte, offentlige verden ikke stivner eller tvinger oss til å innta former som er døde og gjør våre personer til klisjeer. Forfatterens rolle, og den 
intellektuelles rolle, er å skape nye mulighetsbetingelser for individets offentlige opptreden, og på denne måten bidra i et allment frigjøringsprosjekt.

Et ironisk poeng her, gitt Solstads politiske forhistorie som medlem av AKP-ml, er at den potensielle frigjøringen kan sees som en slags kvasi-aristokratisk, konservativ estetisme. Mange av Solstads debattanter var ivrige i å påpeke denne ideologiske selvmotsigelsen (Wedberg, 2003). Sennett er selv inne på det potensielt konservative, i negativ forstand, i det å beskrive utviklingen av offentligheten som en forfallshistorie: "It is difficult to speak of civility in modern life without appearing to be a snob or a reactionary" (Sennett, 1977: 264). Sennett fremholder imidlertid at den konservative kritikken av privatiseringen av det offentlige også rommer en kritikk av det borgerlige samfunn. 1800-tallets romantiske bevegelse og borgerlige kultur strevde ifølge Sennett med bildet av et grenseløst selv. Sennett argumenterer for at offentlighetens krav til formbevissthet og forstillelse bidro til å skape grenser for selvet. Da denne offentlighetskulturen forvitret, gikk muligheten til en sosialt forankret begrensning av selvet tapt. Dermed ble det borgerlige individs forvirring forsterket: "[...] the end of a belief in public culture is not a break with 19th Century bourgeois culture, but rather an escalation of its terms" (Sennett, 1977: 262).

\section{Allegori}

I Sennetts fremstilling ligner historien om den europeiske borgerlige offentlighet en tragedie, ikke ulik Habermas' teori om en offentlighet som etter å ha oppstått som føydalsamfunnets historisk-dialektiske motpol, til slutt faller for sine egne grep og hensynker til reføydalisert privathet. Solstads anekdotiske bevis for tilstanden til dagens norske dannelsesarenaer er også slike forfallshistorier: de er allegorier over den siviliserte offentlighets død. ${ }^{9}$ Kritikerne av Om meddelelsens problem, herunder Kjærstad, Riley, Lending, Bjørnstad m. fl., reagerer på essayets melankolske tone; det beskrives som en "elegi", en "klagesang", et uttrykk for en gammel manns tretthet og lede.

Kjersti Bale har i sin doktoravhandling Om melankoli undersøkt de former for retorikk og poetikk som er forbundet med det melankolske sinnelag. Hun framstiller denne forbindelsen som en transhistorisk litterær konfigurasjon. Fenomenet er karakteristisk for den intellektuelle dikter: På grunn av sitt stadig vekslende temperament, i spennet mellom inspirasjon og galskap, står dikteren i fare for å henfalle til acedia (livstretthet) eller melankoli (tungsinn). Dikterens inspirasjon kanaliseres gjennom en evne til fremstilling som typisk kommer til uttrykk som metaforer og allegorier. ${ }^{10}$ Med referanse til Walter Benjamins analyse av det barokke sørgespillet (Trauerspiel) viser Bale hvordan spesielt allegorien som retorisk figur kulturhistorisk har vært knyttet til et blikk for forfall, fremmedgjøring og

\footnotetext{
${ }^{9}$ En anekdote kan som retorisk figur sammenlignes med en lignelse eller parabel. Parabelen regnes som en undergruppe av allegorien (Abrams, 1988: 4-7). Eide definerer allegori som "forstørret metafor" (Eide, 1999: 15).

${ }^{10}$ I Aristoteles' poetikk, skriver Bale, blir dikterens mimetiske evne oppfattet som evnen til å "gjøre seg annerledes”, til å "fremstille seg som en annen" (Bale, 1997: 32).
} 
meningstap. "Allegorikeren oppdager hva gjenstandene fremstiller: forgjengelighet; han oppdager at verden er forfallen" (Bale, 1997: 155). ${ }^{11}$

Som tankefigur representerer allegorien en verden hvor vi ikke lenger fester lit til noen høyere mening. Allegorien siterer og fryser det øyeblikket hvor en høyere meningsorden går tapt. Den fungerer dermed som en påminnelse om mening som har vært, men som vi alltid vil ha en distanse til. Ved å peke på muligheten for dette (det har faktisk vært) gir den inntrykk av håp (det kan igjen oppstå), men ved å avbilde mening i en fastfryst tilstand (altså som dødt), sier den samtidig at dette håpet aldri helt kan innfris (det vil alltid unnslippe). Gjennom allegorien erfarer $v i$ at meningen unnslipper idet vi forsøker å gripe den.

I en avfortryllet verden gjenstår de motsetningene som symboliserer den tapte orden. Solstads anekdoter er siterende allegorier som beskriver fortidens skolevesen og akademi på den tiden disse institusjonene fremdeles kunne forvalte kulturarven og deres representanter kunne fremstå med verdighet og en smule forfengelighet. Kort sagt, institusjonene var kulturelt meningsbærende. Solstad konstaterer den norske intelligentsias angivelige forfallshistorie. Likevel, eller nettopp derfor, kan han fremstå som en slags redningsmann. "Det er bare den utvalgte melankoliker som er i stand til å oppdage tingene i avmytologisert tilstand som forgjengelighet. Paradoksalt nok er slik allegorien på den ene side avmytologisering, på den annen side blir allegorikeren selv og hans virksomhet gjenstand for mytologisering. Han er utstyrt med en særlig evne som ikke finnes hos andre". ${ }^{12}$ På denne måten fremstår Solstad som Den Store Dikteren.

\section{Stil}

Et karakteristisk trekk ved de to anekdotene er forekomsten av omstendelige formuleringer som stadig gjentas, nærmest som variasjoner over temaer. Man skulle tro at Solstad som forfatter er vár for at leserne etter hvert får poenget med seg, og at han vil prøve å unngå å gjenta seg selv. Det ville være enkelt med få ord å vise til tidligere utsagn, for eksempel "elevens drøftelse" eller lignende, i stedet for å gjenta "drøftelse av moralske dilemma" om og om igjen. Men det er et gjennomgående trekk ved Solstads stil å bryte med slike tekstøkonomiske prinsipper. Om ikke annet vil denne talemåten bli stående som et vitnesbyrd om en slags formmessig gjenstridighet og stahet, et tegn på motstand mot mediets

\footnotetext{
${ }^{11}$ Den forfallenhet som iverksettes med den allegoriske talehandling har sin parallell i den falne verdens status i religiøs diskurs. Også dette peker i retning av at Solstad speiler en geistlig retorisk modus.

${ }^{12}$ I "The Dialectic of Enlightenment Read as Allegory” (1988) analyserer van Reijen, også i lys av Benjamin, allegoriens plass som et typisk retorisk element i postmoderne tenkning. For van Reijen inntrer allegorien som "figure of thought" på det tidspunkt moderniteten har sitt historiske høydepunkt, det vil si når alt håp om en høyere, åpenbar mening er borte. "The allegorical person has lost sight of revelation; he can only see the transient world, the world of the profane" (van Reijen, 1988: 417). "[...] under the gaze of the melancholic the object turns into allegory, it is saved as something that is defunct" (van Reijen, 1988: 419).
} 
informasjonseffektivitet. Dette er for øvrig i tråd med hva Kjartan Fløgstad ga uttrykk for i sin kommentar til debatten, her i et avisintervju:

Problemet er å meddele seg under informasjonskapitalismen. [...] Det henger sammen med den overfylte mediehverdagen vi lever i. Den som vil bli vis i dag må ikke søke informasjon, men søke å unngå den. [...] La oss si at ca. 95\% av all informasjon er usann, feilaktig, fordummende. Samtidig tror jeg at de som er yngre enn meg har lært å beskytte seg bedre, ofte ved kynisme, men også gjennom stilbevissthet (Ullmann, 1997).

Stilbevissthet kan nettopp sies å være et karakteristisk trekk ved Solstads retorikk. Med en informasjonsteknisk term kunne vi si at Solstads språk er preget av redundans, det vil si informasjonsoverflødighet. Solstad gir til beste langt mer informasjon enn det som strengt tatt er nødvendig for å formidle budskapet. Solstads stil kan slik sett sees som et krav om leserens oppmerksomhet og tid. I tillegg til de omstendelige formuleringene og gjentagelsene, ser vi lange setninger og utstrakt bruk av setninger bundet sammen av komma. Solstad avslutter ikke setningen når poenget er sagt, han fortsetter til poenget er iverksatt.

Dette er særlig tydelig når vi tar i betraktning det trivielle faktum at teksten er mye lengre enn et typisk debattinnlegg i en avis. Dette påpekes i noen av svarinnleggene, bl.a. av Kvalshaug, “[...] Solstads kilometerlange essay [...]” (Kvalshaug, 1997), og Kjærstad: “Jeg kan ikke huske når noen, hverken intellektuelle eller andre, fikk meddele seg om noe som helst over en hel side i en av landets største aviser" (Kjærstad, 1997). Essayets lengde er i seg selv en manifestasjon av Solstads overordnede prosjekt på et lett synlig materielt nivå: leseren kan ikke unngå å erkjenne, bevisst eller ubevisst, den særstilling forfatteren av denne teksten må ha. Denne erkjennelsen nås uavhengig av eventuelt forutgående kjennskap til forfatterens status.

Essayets lengde forutsetter at leseren tar seg bedre tid. Solstad støter fra seg den leseren som raskt blar gjennom avisen på jakt etter nyheter eller nyttig informasjon. Implisitt etableres igjen et skille mellom to typer lesere: den tålmodige og den effektive. Dette gjenspeiler et skille mellom det vi kan kalle en aristokratisk/estetisk og en utilitaristisk holdning til tid: den dvelende, reflekterende, fabulerende og langsomme tid, og den effektive, rasjonelle, nyttekalkulerende, matematiske, hurtige tid. Essayets stilltiende protest mot hastverkets lesning kan også knyttes til langsomhet som en slags politisk motstand mot senkapitalismens tingliggjørende og rasjonalistiske samfunnsorganisering.

Den temporale organiseringen av teksten kan også sees som et uttrykk for rytme og musikalitet. Kjærstad kaller teksten "mollstemt", og en "klagesang" (Kjærstad, 1997). Bjørnstad bruker uttrykket "svanesang” (Bjørnstad, 1997). Solstad selv bruker uttrykket "muzzak" for å betegne det kommersielle, automatiserte språk. Formbevisstheten i Solstads retorikk manifesterer seg som et forsøk på å bryte språkets musikalske klisjeer, og skape et språk som fremstår som musikalsk meningsbærende (enten man liker denne musikken eller ikke). I den grad han lykkes, kan vi anta at teksten krever en særlig form for lydhørhet fra publikums side. Den musikalske strukturering av teksten er et middel til å få leseren (i denne 
sammenheng kunne man kanskje sagt lytteren) til å orientere seg i lesningsrommet på en annen måte.

\section{Ironi og forstillelse}

Solstad ønsket å skape debatt, kanskje også å provosere. Skal man dømme etter reaksjonene, lyktes han i så fall med dette. Et eksempel er reaksjonene som gikk ut på at teksten er kvinnediskriminerende. Bakgrunnen er måten Solstad refererer til tekstens kvinnelige hovedperson, den 19 år gamle eleven om strøk til eksamen. Denne unge kvinnen er, til tross for sin flinkhet og pliktfølelse, først og fremst naiv. Den personen som ikke klarer å skille mellom offentlig og privat, som er på evig jakt etter å stille sine banale behov, og som derfor ikke er moden nok til å tre inn i det offentlige rom, er en pike. Den forfatteren som representerer den vulgære litteraturen, er en kvinne. Publikum, som skal representere den inkompetente leser, består av "jentunger": "I stedet for å forvalte kulturarven virker det som om dagens norsklærere er mer opptatt av å stimulere smaken til 19 år gamle jentunger”.

Koblingen mellom naivitet, intimitet, umodenhet og femininitet er neppe helt tilfeldig. Det er en provokasjon. Om den ikke er planlagt, så er den i det minste påfallende i den forstand at Solstad unnlater å ta hensyn til den opposisjon som han innser vil oppstå hos en mengde lesere. Forfatteren kan her sies å drive et retorisk spill. Han legger på sett og vis ut en felle. Den indignerte eller emosjonelt eksalterte leser har nemlig to valg: enten å ta til motmæle åpent og direkte, hvilket innebærer at man har latt seg styre i den retning forfatteren ønsker og dermed vist et tegn på manglende retorisk selvkontroll, eller man kan ta til motmæle skjult og indirekte, hvilket innebærer at forfatteren tilsynelatende slipper unna med sine implisitt provoserende påstander.

Det er derfor et visst hold i påstanden om at Solstads kvinnefremstilling i denne teksten er nedlatende. Det Solstad gjør, er å underforstå en konstruert kvinnelig leser med stereotype negative trekk. Dette er i seg selv en dogmatisk og nedlatende holdning, dømt til å skape strid og støte lesere fra seg. Man kan likevel diskutere hvorvidt de totalt seriøse polemiske responsene på Solstads åpenbare provokasjoner er adekvate. Etter min oppfatning er Solstads dogmatisme og autoritære stil en form for forstillelse, et trekk ved hans tekstlige persona. Solstad innretter seg slik at hans provokasjoner ikke skal tas helt alvorlig, uavhengig av hvor alvorlig Solstads motiver har vært. Det er i lys av dette vi bør lese følgende uttalelse fra Kjærstad:

I sitt lange, mollstemte innlegg demonstrerer Solstad at han forbeholder seg retten til å oppføre seg med et visst snobberi, som en forfengelig representant for en elite, en som forvalter kulturarven, en som mener at et verdihierarki er nødvendig. Det er greit. Jeg ser ikke noe problem i det. Jeg tror det er ønsketenkning at noen skulle se et problem i det (Kjærstad, 1997).

Kjærstads respons kan sies å være adekvat i den forstand at den plasserer seg på det samme ironiske nivået som Solstad opererer på. For det første viser han frem det kunstferdige ved 
Solstads provokasjoner: Solstad "forbeholder seg retten" til "å oppføre seg” som en kulturell snobb. Kjærstad sier ikke at Solstad er en snobb. Poenget her er ikke å diskutere hvorvidt den biografiske Solstad "egentlig" er en snobb eller ikke (dette er irrelevant), men å vise at det å lese Solstad er å forholde seg til en snobbete tekstlig karakter. Solstad som snobb er en persona, en fiksjon, som skaper både forvirring og fascinasjon: Hvem kan det være som fremstiller seg slik?

Men forventningen om at noen skulle se et problem i dette snobberiet, er ifølge Kjærstad et uttrykk for ønsketenkning. Solstads ønsketenkning består i å ønske seg en bestemt lesertype, som Kjærstad mener ikke finnes. Det Kjærstad gjør er å peke på Solstads tendens til å underforstå ulike lesertyper. Dermed avslører han spillet og bryter den retoriske illusjonen. Ved å vise seg som en annen type leser enn de typene Solstad impliserer (for eller imotleserne), prøver Kjærstad å undergrave Solstads ironisk/retoriske prosjekt. Han nekter å la seg naivt kategorisere $\mathrm{i}$ henhold til tekstens skjema for impliserte lesertyper. Kjærstad bedriver en form for anti-ironisk lesning, en lesning som skal berøve Solstad noe av hans ironiske kraft, nettopp ved å vise ham frem som en som 'spiller'. Kjærstad praktiserer den form for lesermotstand som han mener Solstad selv ber om, uten å bli bønnhørt.

Kjærstad 'åpner' Solstads tekst for publikum, han utøver en slags folkelig motstand mot Solstads elitisme. Et poeng er at den eneste effektive måten å demonstrere slik motstand, er ved å innta en leserposisjon som komplementerer Solstads tekst. Motstanden er en respons på Solstads provokasjon. Avvæpningen av forfatterens ironiske språkhandling kan bare skje gjennom en tilsvarende anti-ironisk leserhandling. Spørsmålet er om dette skal tolkes som en etterkommelse av Solstads ønske om motstand, og dermed som at Solstads prosjekt faktisk har lykkes, eller om dette er en overskridelse og kritikk av Solstad, og dermed en demonstrasjon av Solstadprosjektets utilstrekkelighet. Jeg nøyer meg her med å antyde dette som et mulig paradoks.

Det kan stilles spørsmål ved om den totalt seriøse respons er adekvat, fordi Solstad praktiserer en form for forstillelse som skal gjøre hans private meninger irrelevante. På dette punkt er Solstads tekst retorisk sett raffinert: Han praktiserer en form for ironi som er akkurat passe skjult. Men dette kan sies å være nøyaktig ironiens funksjon: Å være tilstrekkelig skjult og tilstrekkelig åpen. ${ }^{13}$ På den ene side såpass skjult at man unnslipper det banale, på den andre siden såpass åpen at man blir forstått. Slik sett er den solstadske ironien en direkte respons på, og dermed også en tydelig manifestasjon av, det intellektuelle dilemma jeg skisserte innledningsvis: Hvordan opptre med intellektuell integritet $i$ et kommunikativt klima man ikke aksepterer?

Som tidligere nevnt kan Solstads form for spill og forstillelse karakteriseres som konservativ estetisme. Samtidig kan den sies å være en særskilt form for postmoderne ironi:

\footnotetext{
${ }^{13}$ Her er det på sin plass å nevne ironiens slektskap med allegorien. I begge tilfeller dreier det seg om en "fremstilling som skal forstås i en annen betydning enn den bokstavelige" (Eide, 1999: 15), eller "å si noe annet enn det en mener [...]" (Andersen, 1995: 72). Men for både ironi og allegori gjelder at skal de kunne fungere, må det være et tilstrekkelig intuitivt slektskap mellom de to områdene som figurene sammenstiller “[...] slik at en vil bli forstått” (Andersen, 1995: 72).
} 
Den reaksjonære dogmatiske positur kan sees som en seriøs ironisk holdning. Ifølge Slavoj Žižek, er dette en form for ironi som er typisk for den postmoderne (eller med hans betegnelse: senkapitalistiske) epoke: "Så det er altså på ein måte som om reaksjonane er snudd heilt på hovudet, er eg freista til å seia. Karneval er seinkapitalistisk normalitet. Derfor må dei som er kritiske spela stabile, konservative, nesten dogmatiske" (Fløgstad og Søbye, 2002: 72).

Denne analysen er treffende for Solstads form for ironi. Det er et forsøk på et språkkritisk prosjekt i en tid hvor de fleste tilløp til slik kritikk assimileres av den dominante kommersielle kultur, enten gjennom reklamen, som tar opp i seg alle avantgardistiske formeksperimenter og gjør dem salgbare, eller gjennom underholdningsindustrien, som ufarliggjør kritikken og omskaper den til atspredelse. Når de kritiske fremmedgjørende grep blir institusjonalisert og mainstream, mister de sin subversive kraft. Gjennom en historiskdialektisk reversering av forholdet mellom makt og kritikk, må kritikken spille seriøs for å vore seriøs. Vekslende historiske omstendigheter medfører forskjellige strategier for å uttrykke motstand. Dette gjelder også motstand i form av ironi.

\section{Posisjonering}

Med den tekstlige persona som skapes ved ironi, spill og forstillelse fiksjonaliserer forfatteren sin offentlige tilstedeværelse. Dag Solstad har ikke vært alene om å gjøre seg bemerket på denne måten, det er nok å nevne Karl Ove Knausgård for å slå fast at denne typen selvfremstilling er en litterær tendens som har vakt stor offentlig interesse. Når fiksjon og selvbiografisk prosa flettes inn i hverandre på oppfinnsomme måter, oppstår det usikkerhet om når forfatteren uttrykker seg som seg selv og når han uttrykker seg som fiksjonens innskrevne forfattersubjekt. ${ }^{14}$ Dette skaper fascinasjon og nysgjerrighet hos leseren. Kanskje Solstad er like mye forfatter, og like mye seg selv, i begge varianter? Så hva eller hvor er egentlig det området der forfatteren hører hjemme?

Inger Østenstads omfattende diskursanalyse av Solstads forfatterskap er i visse henseender en avspeiling av denne tendensen. Med begreper lånt fra Dominique Maingueneau tenker hun seg Solstads forfatterskap som en sammensetning av "det kanoniske rommet" og det "tilsluttende rommet" (Østenstad, 2009: 86). I det kanoniske rommet finner vi de skjønnlitterære tekstene som gjør at forfatteren blir Forfatter, i det tilsluttende rommet finner vi "like viktige" (men "mindre prestisjefulle") tekster, for eksempel artikler, intervjuer, kritikk og avhandlinger (Østenstad, 2009: 86). Solstads forfatterskap er med andre ord det diskursive området som skapes i og med alle publikasjonene $a v$ og om ham. ${ }^{15}$

\footnotetext{
${ }^{14}$ Både Østenstad (2009: 88) og Hjorthol (2011: 37) kommenterer denne siden ved Solstads forfatterskap. Men det må nevnes at det å blande fiksjon og sakprosa i seg selv ikke er noe nytt litterært fenomen, blant annet er det et utpreget trekk ved Milan Kunderas forfatterskap, hvis slektskap med Solstads er nevnt i Vold (1987: 80), og diskutert i Wedberg (2003: 107-117) og Wedberg (2012: 148).

${ }^{15}$ Sosiologisk sett er forestillingen om et diskursivt rom beslektet med forestillingen om et offentlig rom.
} 
I dette perspektivet blir verdien av typer av meddelelser (eller "utsigelser" i Østenstads terminologi) objektivert og relativert. Østenstad legger forfatterskapet inn under spørsmålet 'Hvorfor så stor?', eller med andre ord: Hvordan forklare at Solstads forfatterskap har blitt så vellykket? I spørsmålsstillingen ligger en hypotese om at alle elementer i forfatterskapet, også de ikke-kanoniske, spiller en viktig og konstruktiv rolle. I så måte er Østenstads spørsmålsstilling beslektet med min egen: Hvorfor og hvordan lyktes Solstad med å prege det offentlige ordskiftet med en kronikk som denne?

I Østenstads fremstilling dreier det seg om å beherske de spesifikke, konstituerende mekanismene som bidrar til en forfatters prestisje og skaffer ham en posisjon. Med et oppsummerende begrep beskriver Østenstad den intellektuelle forfatterens situasjon som paratopisk. Den gjennomslagskraftige forfatter plasserer seg både innenfor og utenfor det litterære sentrum; han er ikke bare topisk (på stedet), men para-topisk (ved stedet). Forfatteren lykkes altså når han finner den rette balanse mellom å følge og bryte den litterære institusjonens konstituerende mekanismer. ${ }^{16}$ Østenstad viser hvordan Solstad gjennom hele sin karriere effektivt har manøvrert seg frem ved å beherske denne balansegangen, og trekker frem at Solstad selv har reflektert over sin forfattergjerning langs disse baner (Østenstad, 2009: 141).

Den retoriske analysen av Om meddelelsens problem avdekker også en bevissthet om spillets regler. Jeg har argumentert for at selve utførelsen av spillet indikerer visse hensikter og motiver, fremfor alt et motiv om å utsette publikum for en alternativ form for offentlig deltagelse. Østenstad slutter seg til Derridas utsagn om at den litterære institusjon er knyttet til tilblivelsen av den moderne ideen om demokrati (Østenstad, 2009: 352). Det betyr i så fall at deltagelse i det litterære "spillet" er "deltagelse i å fremkalle demokratiet", for å bruke hennes egne formuleringer. Nettopp denne kjensgjerning gir et holdepunkt for å hevde at Solstads meddelelse er paradoksal: Selve meddelelsen er utført som en kritikk av det senmoderne samfunnets rammer for demokratisk deltagelse. ${ }^{17}$

\footnotetext{
${ }^{16}$ Dobbeltheten i den paratopiske posisjon kan sies å komme retorisk til uttrykk i det jeg i en annen Solstad-analyse har kalt "rhetoric of duplicity" (Wedberg, 2012).

${ }^{17}$ Østenstad har bevisst "ikke fortolket verkene for å finne ut hva de "betyr" eller dypest sett utsier" (Østenstad, 2009: 350). Det har imidlertid vært nøyaktig min ambisjon: Å finne ut hva akkurat denne kommunikative hendelsen kan tenkes å bety, med andre ord å tilføre "diskursen” mitt eget perspektiv, som forhåpentlig er noe annet og mer enn det som ligger i den fra før. Østenstad skriver om Solstads verk generelt at de er "så fortolkbare" (Østenstad, 2009: 350). Denne fortolkbarheten kan etter mitt syn forstås som den utforming som gir dem særlig appell; som de måtene verkene taler til deg på. Analysen forsøker å svare på denne tiltalen: Jeg har simpelthen forsøkt å finne ut på hvilken måte denne meddelelsen appellerer. Retorisk kritikk kan være tjenlig i så måte: Å kombinere et blikk for meddelelsens hensikt og et øre for kvalitetene i forfatterens stemme. Ved både å se det som blir gjort og lytte til det som blir sagt, kan meddelelsen begripes som et stykke kunstferdig ordbruk i praksis.
} 


\section{Tilbaketrekning?}

I avhandlingen Tilbaketrekninga: Litteraturens politikk i Dag Solstads forfatterskap (2011), tar Geir Hjorthol for seg det han kaller "Solstads litterære utforsking av den intellektuelles posisjon" og vier Om meddelelsens problem en lengre drøftelse (Hjorthol, 2011: 181). Hjorthol viser at lesernes respons er ambivalent og forklarer det med et tenkt skille mellom sakprosaforfatteren Solstad og fiksjonsforfatteren Solstad. Ifølge Hjorthol henger kritikerne fast $i$ “[...] eit forenkla skilje mellom diktning som "rein fiksjon" og sakprosaen som eit autentisk uttrykk for forfattarens syn" (Hjorthol, 2011: 37). Hjorthol hevder derimot at det er "[...] ein nær relasjon mellom fiksjon og sakprosa hos denne forfattaren både tematisk, formelt og referensielt, men den er ikkje eintydig" (Hjorthol, 2011: 37). Relasjonen består ifølge Hjorthol ikke i at "sakprosaforfatterens ærlige meninger får gjennomslag i forfatterens fiksjonslitteratur", men i en forbindelse på et teoretisk nivå som er felles for dem begge, i det han kaller "fiksjonen bortanfor fiksjonen: ein berande fantasi som utgjer ramma for subjektets røyndomsoppfatning” (Hjorthol, 2011: 38).

Fortolkningsrammen for denne fiksjonen finner Hjorthol hos Jacques Rancière og Slavoj Žižek. Den går ut på at det vi oppfatter som vårt autentiske jeg er en speiling av en symbolsk samfunns-autoritet. Ifølge Hjorthol er det slik ideologier virker; våre unike selv blir skapt i kontrast til "Den store Andre". Jeg-følelsen er altså en "dobbel illusjon", en innbilt forskjell fra en symbolsk Andre "som ikkje finst [...] Dette vi kallar realitetar byggjer på ein naudsynt illusjon, ein fundamental fantasi om ei sanning som stikk djupare enn den 'trivielle realiteten' vi ser framfor augo våre" (Hjorthol, 2011: 58). ${ }^{18}$

Når Hjorthol lytter etter Solstads stemme, ledes han altså til et språklig nivå ovenfor fiksjon og sakprosa. Der hører han det jeg vil kalle en eksistensiell sound of silence. ${ }^{19}$ I Hjorthols analyse er derfor Solstads litteraturpolitiske bevegelse å forstå som en slags forsvinning, en “tilbaketrekning" (Hjorthol, 2011: 38).

Hjorthols konklusjon om Solstads romanpersoner er i tråd med Kvalshaugs anklage mot forfatteren Solstad; en anklage om manglende deltagelse og tilbaketrekning fra samfunnslivet. Solstads svar i “Om meddelelsens problem” synes først å bekrefte anklagens påstand: En dekadent offentlighet bestående av selvtilfredse konsumenter er et håpløst utgangspunkt for en opplyst kulturdebatt og derfor trekker han seg tilbake fra offentlighetens

\footnotetext{
${ }^{18}$ Det ser ut til at det filosofiske forelegget for disse teoriene er Nietzsches forestilling om "Leben in schein", det vil si illusjonens nødvendighet for opprettholdelse av personlig vitalitet, en form for aktiv nihilisme. I det kritiske essayet "Poetic reason in Nietzsche" beskriver Stanley Rosen hvordan Nietzsche tenker seg denne illusjonen skapt av "der dichtende Vernunft": "The true essence of things is an invention of representing Being. [...] each world or human perspective is for Nietzsche a work of art, not in the sense of an intentional product of technical creation, like a poem or a symphony, but rather in the sense of a representation (Vorstellung) produced by the fantasizing or "poeticizing" reason. [...] As an illusion, however, it is necessary for life, which is representation, or the projection of order onto chaos, the ultimate substratum" (Rosen, 1987: 211).

${ }^{19}$ Hjorthols metafiksjon høres ut som en nihilistisk variant av allegorikerens falne verden. Den vitner om noe transcendent, men den transcendentale kilden er tom.
} 
lys. Dette er kronikkens argument, men det har vært et hovedpoeng i min fremstilling å vise at det skjer en vel så viktig overbevisning på et annet nivå enn det åpent argumentative; det er i selve talehandlingen denne teksten har sitt vesentlige argumentative potensial.

Solstad trekker seg kanskje tilbake, men ikke ved å forsvinne; snarere ved å utføre en talehandling som annonserer en alternativ måte å være tilstede på i offentligheten. Ved å fiksjonalisere sitt debattinnlegg spiller han en påfallende rolle som litteraturens talsmann, og dermed utvides litteraturens rom. I et litteratursosiologisk perspektiv kan denne utvidelsen sees som et ledd i en motstandskamp under mottoet om at angrep er det beste forsvar. Sakprosaforfatteren og fiksjonsforfatteren danner felles front: De kjemper sine litterære slag med de våpen de har for hånden.

Solstad sier ikke bare at den offentlige samtale er hemmet av en vulgær forbrukermentalitet; i og med sin meddelelses form gjør han oppmerksom på hvordan forbrukerkulturens samhandlingsmønstre kommer til uttrykk i det offentlige meddelelsesrom. Ved insisterende narrativitet, ironisk forstillelse og stilistiske avvik henleder han oppmerksomheten mot de mekanismene som definerer mulighetsrommet for meddelelse; mekanismer som ligger latent i det offentlige rom, men som er mer eller mindre usynlige.

En vesentlig del av kronikkens appell skriver seg fra dens egenskap av å være en demonstrasjon av sitt poeng. Det er en tekst som ikke bare "sier det", den "viser det" også. En slik fremstillingsform defineres gjerne med betegnelsen mimesis. Hjorthol distanserer seg imidlertid eksplisitt fra dette begrepet. Han refererer til Solstads eget utsagn i et intervju med Jan Landro, om at mottoet "show it, don't tell it" bevisst brytes: Solstad vil nettopp ikke vise, men fortelle (Hjorthol, 2011: 74).

Ifølge Trond Haugen har Solstad gjennom hele sin sakprosakarriere hatt et mer eller mindre bevisst forhold til mimesis. Solstad tok tidlig avstand fra den psykologisk-realistiske litteraturen: "Det estetiske grunnlaget for denne kritikken var en avvisning av forståelsen av litteratur som en mimetisk gjengivelse av virkeligheten" (Haugen, 2012). Men etter hvert forandrer han posisjon: "Han ønsker å vende tilbake til verden” (Haugen, 2012). Men det er ingen naiv realisme Solstad vender tilbake til, det er en verden som "bare blir verden når den blir fortolket. [...] Formen er verden. Verden er form. Dermed kan en si at Solstad [...] rehabiliterer realismen på en måte som opprettholder avvisningen av den. Han åpner for muligheten av en realisme som ikke er mimetisk. Eller hvis leseren heller foretrekker det: en mimetisk litteratur som ikke er realistisk" (Haugen, 2012). Haugens påstand om ikkerealistisk mimesis er et paradoks beslektet med min egen konklusjon: Solstads fortelling har en mimetisk funksjon. På sett og vis kan man si at Solstad vender om på forholdet mellom skjønnlitteratur og sakprosa: Han er kompromissløst fortellende på skjønnlitteraturens område, hvor en "show, don't tell" - holdning er dominerende, mens den argumentative sakprosaen fremstår som iscenesatt.

Solstads proklamerte tilbaketrekning er i realiteten en fremrykning. Den mye omtalte “episke nødvendighet" slår igjennom ikke bare i hans romaner, men i og som hans persona. I tillegg til den skjønnlitterære produksjon, er dette en av de egenskapene som har befestet Solstads posisjon: Han viser seg offentlig som forfatter konsekvent; det vil si som forfatter og 
ikke noe annet. I slike situasjoner fremstår Solstad gjerne som utilpass og tilbakeholden, men det svekker ikke forfatterskapets posisjon og troverdighet.

Og da er jeg nærmere et svar på mitt innledende spørsmål: Publikums veksling mellom beundring og fordømmelse er en respons på den form for litterær meddelelse som Solstad personifiserer; en form for tiltrekkende distansering som er etterspurt i en offentlighet som ellers er preget av overveldende åpenhet og meddelsomhet.

\section{Litteratur}

Abrams, M. H. (1988). A Glossary of Literary Terms (4. utg.). New York: Holt, Rinehart and Winston Inc. Andersen, Øyvind. (2004). I retorikkens hage (5. utg.). Oslo: Universitetsforlaget.

Arendt, Hannah. (1996). Vita activa: det virksomme liv. Oslo: Pax.

Bale, Kjersti. (1997). Om melankoli. Oslo: Pax.

Bjørnstad, Ketil. (1997). Svanesang og arroganse. Aftenposten, 2. juli.

Eide, Tormod. (2004). Retorisk leksikon. Oslo: Spartacus.

Fløgstad, Kjartan og Søbye, Espen. (2002). Filosofisk punk rock opera. Samtale med Slavoj Žižek. Samtiden, nr. 5. Oslo: Aschehoug.

Haugen, Trond. (2012). Virkelighetens stil. Noen nedslag i Dag Solstads sakprosa-forfatterskap. Prosa (på nett), nr. 1.

Hjorthol, Geir. (2011). Litteraturens politikk i Dag Solstads forfatterskap. Doktoravhandling ved NTNU, Trondheim.

Kjærstad, Jan. (1997). Klagesang fra vernet mann. Aftenposten, 1. juli.

Kjærstad, Jan. (1997). Menneskets felt. Oslo: Aschehoug.

Kvalshaug, Vidar. (1997). Forarget over etablerte forfattere. Aftenposten, 18. juni.

Kvalshaug, Vidar. (1997). Gi den mannen en smoking! Aftenposten, 4. juli.

Lending, Mari. (1997). Umoralsk nostalgi. Aftenposten, 25. juli.

Reijen, Willem van. (1988). The Dialectic of Enlightenment Read as Allegory. Postmodernism . Theory, Culture \& Society, vol. 5. London: Sage.

Riley, John Erik. (1997). Om den kritiske kultur-konsumenten. Aftenposten, 7. juli.

Rosen, Stanley. (1989). The Ancients and the Moderns. New Haven and London: Yale University Press.

Skre, Arnhild. (2002). "Vil ikke ha Fr.p.-lesere". Intervju med Dag Solstad. Aftenposten, 17. oktober.

Sennett, Richard. (1977). The Fall of Public Man. Cambridge: Cambridge University Press.

Solstad, Dag. (1997). Om meddelelsens problem. Aftenposten, 27. juni.

Solstad, Dag. (1998). 3 essays. Oslo: Oktober forlag.

Solstad, Dag. (2000). Artikler om litteratur. Oslo: Oktober forlag.

Sørensen, Per Olav. (1997). Solstad satte punktum. Dagbladet, 7. august.

Tusvik, Marit. (1997). Å bli forfattar - å vere forfattar. Aftenposten, 15. juli.

Ullmann, Linn. (1997). Vi lever i en ideologisk natt. Intervju med Kjartan Fløgstad. Dagbladet, 3. september.

Vold, Jan Erik. (1987). Imaginasjon. Intervju med Dag Solstad. Samtiden, nr. 5, s. 61-80.

Wedberg, Kristian. (2003). Littercer offentlighet og opplysningens dilemma. Hovedoppgave ved Institutt for medievitenskap, Universitetet i Bergen.

Wedberg, Kristian. (2012). Dis-playing Democracy: The Rhetoric of Duplicity. Christian Kock \& Lisa Villadsen (Red.). Rhetorical Citizenship and Public Deliberation (s. 157 - 172). Pennsylvania: Pennsylvania State University Press.

Økland, Ingunn. (1998). Solstad-debatt på nordisk nivå. Aftenposten, 7. august.

Østenstad, Inger. (2009). Hvorfor så stor: En littercer diskursanalyse av Dag Solstads forfatterskap.

Doktoravhandling ved Det humanistiske fakultet, Universitetet i Oslo. 